\title{
Pre-service Science Teachers' Critical Thinking Dispositions and Critical Thinking Skills
}

\author{
Amiq Fikriyati ${ }^{1, *}$ Rudiana Agustini ${ }^{2}$, Suyatno Suyatno ${ }^{3}$ \\ ${ }^{1,2,3}$ Doctoral Program of Science Education, Postgraduate of Universitas Negeri Surabaya \\ "Corresponding author. Email: amiafikriyati87@gmail.com
}

\begin{abstract}
Critical thinking disposition and critical thinking skills are essential parts of critical thinking that are mutually reinforcing. This study is aimed to describe and examine the relationship between critical thinking dispositions and critical thinking skills of pre-service science teachers. In this research, the quantitative descriptive method is utilized. Fifty pre-service science teachers have participated in this study. The instruments that used in this study are a critical thinking dispositions inventory and critical thinking skills test. The data were collected using questioner and tests. The results showed that: (1) the critical thinking dispositions of pre-service science teachers on the seven indicators (truth-seeking, open-mindedness, analyticity, systematicity, self-confidence, inquisitiveness, and maturity of judgment) are categorized as low; (2) critical thinking skills of pre-service science teachers on the five indicators (interpretation, analysis, evaluation, inference, and explanation) are categorized as low/still underdeveloped; and (3) the meaningful relationship is found, there is a significant correlation $(r=0.735)$ between pre-service science teachers' critical thinking dispositions and critical thinking skills. An improvement is needed in lecturing the learning model to improve students' critical thinking dispositions and critical thinking skills. Pre-service Science Teachers' Critical Thinking Dispositions and Critical Thinking Skills.
\end{abstract}

Keywords: Critical thinking dispositions, Critical thinking skills, Pre-service science teacher.

\section{INTRODUCTION}

Critical thinking has become an important issue to face the challenge of the industrial revolution 4.0 era [1]. Industrial revolution 4.0 has given both contributions and huge effects on society [2]. Therefore, the education field must prepare a competent output that can compete globally facing the industrial revolution 4.0 era [1][2]. In this era, the rapid growth of technology, information, and communication not only makes our life easier but also brings a new challenge to the education field [3]. As a result, the challenge faced by the education field is to prepare a competence output that can master technology, information, and communication and develop output competency such as critical thinking skills [4].
Critical thinking is logical and reflective thinking that focuses on deciding what is to be believed and done [5]. Critical thinking is needed to make a judgment in accepting information, create an opinion based on right, logical, and objective reasons, and defend the conclusion that is made is right [6]. The core of critical thinking is thinking that is directed on purpose, which is done carefully [7].

Critical thinking not only needs skills to judge the right reason but also needs the disposition to make an action and belief based on reason [5][8]. Researchers have believed in how the importance of critical thinking dispositions besides critical thinking itself [9]. Critical thinking dispositions and critical thinking skills are two different terms in an individual [9][11]. However, critical thinking dispositions and critical thinking skills will strengthen each other [10][11]. 
Critical thinking disposition is an attitude or habit of thinking that keeps an individual motivated to respond on reflective mode [8][10]. Ennis described disposition as a "spirit of investigation." Critical thinking dispositions consisted of truth-seeking, open-mindedness, analyticity, systematicity, confidence in reasoning, inquisitiveness, and maturity of judgment [10]. On the other hand, critical thinking skills, which are part of cognitive skills, consist of interpretation, analysis, evaluation, inference, explanation, and self-regulation [11].

Critical thinking disposition has affected the character and thinking ability of an individual. Researchers have recognized the importance of critical thinking dispositions in addition to critical thinking skills to distinguish a critical thinker from an uncritical thinker [9]. Students who have a high disposition also have a significant influence on their performance in learning activities [21]. The existence of a critical thinking disposition is as important as critical thinking skills [11].

This research is important to be conducted because critical thinking skills are connected to an individual's critical thinking dispositions. There is a correlation between critical thinking dispositions and critical thinking skills [12][13]. Other researchers also showed that critical thinking skills influence problem-solving ability [14], academic achievement at university [12], and web 2.0 competencies [15]. However, some other previous researchers reported that the critical thinking dispositions are still low [13][14][16]. This research is aimed at (1) to describe the critical thinking dispositions of pre-service science teachers, (2) to describe the critical thinking skills of pre-service science teachers, and (3) to examine the relationship between critical thinking dispositions and critical thinking skills of pre-service science teachers.

\section{METHODS}

\subsection{Design and Research Procedure}

This research is classified as correlational research, conducted in one subject group, i.e., preservice science teachers at one of the universities in Surabaya. The correlational research is aimed to examine the associative correlation among research variables [17]. This research is conducted to compare and determine the relationship between critical thinking dispositions and critical thinking skills of pre-service science teachers.

\subsection{Research Instruments}

\subsubsection{Critical Thinking Disposition Inventory}

CTDI instrument is described and adapted from Facione that measures seven indicators, i.e., truthseeking, open-mindedness, analyticity, systematicity, self-confidence, Inquisitiveness, and maturity of judgment [18]. CTDI questionnaire that is consisted of 51 statements is used to collect data about critical thinking dispositions. The CTDI has six subscales with a Cronbach's alpha for the overall scale are 0,92 (high reliability). Those six subscales are scored as follow: 6 points $=$ "I strongly agree", 5 points $=$ "I agree", 4 points = "I agree with part of them", 3 points = "I disagree part of them", 2 points = "I disagree" and last, 1 point = "I strongly disagree".

The components of critical thinking dispositions that are used in the instrument are shown in Table 1.

Table 1. The reliability instrument of CTDI

\begin{tabular}{|l|l|}
\hline \multicolumn{1}{|c|}{ Component } & \multicolumn{1}{|c}{ Measurements } \\
\hline Truth-seeking & $\begin{array}{l}\text { The willingness to find and prove the } \\
\text { information/knowledge bravely and } \\
\text { honestly. }\end{array}$ \\
\hline $\begin{array}{l}\text { Open- } \\
\text { mindedness }\end{array}$ & $\begin{array}{l}\text { The ability to tolerate the difference of } \\
\text { view/belief/idea. }\end{array}$ \\
\hline Analyticity & $\begin{array}{l}\text { The ability to evaluate the probable } \\
\text { problems in reasoning and problem- } \\
\text { solving. }\end{array}$ \\
\hline Systematicity & $\begin{array}{l}\text { Showing the regularity, focus, and } \\
\text { diligence in looking for knowledge. }\end{array}$ \\
\hline Inquisitiveness & $\begin{array}{l}\text { Showing intellectual curiosity and the } \\
\text { willingness to learn, although the } \\
\text { implementation of that knowledge is still } \\
\text { unknown. }\end{array}$ \\
\hline $\begin{array}{l}\text { Confidence in } \\
\text { Reasoning }\end{array}$ & $\begin{array}{l}\text { Showing self-confidence, appreciating } \\
\text { their thinking power, and being able to } \\
\text { guide others to solve problems logically. }\end{array}$ \\
\hline Maturity of \\
Judgment
\end{tabular}$\quad$\begin{tabular}{l} 
Wisdom in making a decision. \\
\hline
\end{tabular}

The last score in each sub-dimension will be counted by summing the scores from the answer in each subdimension from the original scale. Then, the total score will be analyzed and categorized into criteria of CTDI. CTDI score that is collected is analyzed using three criteria, i.e., low level (51-135), medium level (136-220), and high level (221-306) [15].

\subsubsection{Critical Thinking Skill Test}

Critical thinking skills are measured using the Critical Thinking Skill Test (CTST). Twenty-five numbers of tests are developed to measure five indicators of critical thinking skills, i.e., interpretation, analysis, evaluation, inference, and 
explanation [11]. CTST is developed using correct incorrect choices, and it is completed with reason.
The components and indicators of critical thinking skills which are used in CTST are shown in Table 2.

Table 2. The reliability instrument of CTST

\begin{tabular}{|l|l|}
\hline \multicolumn{1}{|c|}{ Component } & \multicolumn{1}{c|}{ Measurements } \\
\hline Interpretation & $\begin{array}{l}\text { Understanding and expressing the meaning of various kinds of problems, data, and finding and } \\
\text { classifying them using certain classifications. }\end{array}$ \\
\hline Analysis & $\begin{array}{l}\text { Identifying problems, inference relationship among statement, question, concepts, description and } \\
\text { so on to express reason, information, or opinion. }\end{array}$ \\
\hline Evaluation & Evaluating the credibility of a statement or other representation \\
\hline Inferences & $\begin{array}{l}\text { Identifying and determining the elements that are needed to draw a logical conclusion and able to } \\
\text { create a hypothesis/claim by paying attention to the relevant information and lessen the } \\
\text { consequence. }\end{array}$ \\
\hline Explanation & $\begin{array}{l}\text { Giving logic, reasonable, convincing opinions based on evidence, methodology, concept, or } \\
\text { certain criteria from various points of view. }\end{array}$ \\
\hline
\end{tabular}

The Cronbach's alpha for this instrument research is 0.85 for all scales. The test result will be analyzed using a critical thinking skills rubric in which the range of its score is 1-4. The critical thinking skills score will be examined and categorized using the following criteria, i.e., not yet visible or still underdeveloped (1-2) or start developing or developing well (3-4) [11].

\subsection{Data Collection}

The subject of this research is 50 pre-service science teachers from Universitas Islam Negeri Sunan Ampel Surabaya. CTDI and CTST are distributed directly to the pre-service science teachers and collected by the researcher herself. Then, the collected data from CTDI and CTST are calculated. These data are analyzed using a simple correlational test of Spearman Rank Product to test the hypothesis, i.e., to determine the significance of the relationship Table 3. Descriptive statistic of critical thinking disposition

\begin{tabular}{|c|c|c|c|c|c|c|c|c|c|c|}
\hline & \multicolumn{2}{|c|}{$\begin{array}{l}\text { Low level } \\
(51-135)\end{array}$} & \multicolumn{2}{|c|}{$\begin{array}{l}\text { Medium level } \\
(136-220)\end{array}$} & \multicolumn{2}{|c|}{$\begin{array}{l}\text { High level } \\
(221-306)\end{array}$} & \multirow[t]{2}{*}{ Mean } & \multirow[t]{2}{*}{ Median } & \multirow[t]{2}{*}{ Sd } & \multirow[t]{2}{*}{ Level } \\
\hline & $\mathrm{N}$ & $\%$ & $\mathrm{~N}$ & $\%$ & N & $\%$ & & & & \\
\hline CTDI & 37 & 62 & 13 & 26 & - & - & 134.2 & 131 & 12.5 & Low \\
\hline
\end{tabular}

The components of critical thinking dispositions of pre-service science teachers are at a low level, i.e., confidence in reasoning, truth-seeking, and analyticity. The components of critical thinking dispositions are at a medium level, i.e., maturity of judgment, systematicity, inquisitiveness, and openmindedness. These results can be seen in Table 4 .

Table 4. The level of each component critical thinking disposition

\begin{tabular}{|l|c|c|}
\hline \multicolumn{1}{|c|}{ Component } & Mean & Level CTDI \\
\hline Truth-seeking & 90.9 & Low \\
\hline Open-mindedness & 109.4 & Low \\
\hline Analyticity & 116.4 & Low \\
\hline
\end{tabular}

between critical thinking dispositions and critical thinking skills of pre-service science teachers.

\section{RESULTS AND DISCUSSION}

\subsection{Critical thinking dispositions}

The critical thinking dispositions of pre-service science teachers still need to be developed further. The complete result of the critical thinking dispositions of pre-service science teachers is presented in Table 3. The descriptive statistics in Table 3 show that generally, the level of critical thinking dispositions of pre-service science teachers is at a low level, in which $62 \%$ are categorized as low level, and $26 \%$ are categorized as medium level. This result shows that the critical thinking dispositions of pre-service science teachers still need to be developed. 
Table 5. Descriptive statistic of critical thinking disposition

\begin{tabular}{|c|c|c|c|c|c|c|c|c|}
\hline & \multicolumn{2}{|c|}{$\begin{array}{c}\text { Underdeveloped level } \\
(1-2)\end{array}$} & \multicolumn{2}{|c|}{$\begin{array}{c}\text { Start developing level } \\
(3-4)\end{array}$} & \multirow{2}{*}{ Mean } & \multirow{2}{*}{ Median } & \multirow{2}{*}{ Sd } & \multirow{2}{*}{ Level } \\
\hline & $\mathrm{N}$ & $\%$ & $\mathrm{~N}$ & $\%$ & & & & \\
\hline CTST & 41 & 82 & 9 & 18 & 48.7 & 38 & 17.04 & underdeveloped \\
\hline
\end{tabular}

These results show that pre-service science teachers' critical thinking skills still need to be developed. These findings have shown that not only the critical thinking disposition of pre-service science teachers who are on the low criteria but also their critical thinking skills. Both the critical thinking disposition and critical thinking skills of pre-service science teachers still need to be developed.

Table 6. The level of each component critical thinking skills
The analysis results for each component of critical thinking skills that have been measured are presented in Table 6. The components of critical thinking skills that are still needed to be developed are evaluation, inference, and explanation. In addition, the components that are starting to develop i.e. interpretation and analysis.

\begin{tabular}{|l|c|c|c|c|}
\hline \multirow{2}{*}{ Component } & \multicolumn{2}{|c|}{ Underdeveloped level (1-2) } & \multicolumn{2}{c|}{ Start developing level (3-4) } \\
\cline { 2 - 5 } & $\mathrm{N}$ & $\%$ & $\mathrm{~N}$ & $\%$ \\
\hline Interpretation & 35 & 70 & 15 & 26 \\
\hline Analysis & 37 & 74 & 13 & 18 \\
\hline Evaluation & 41 & 82 & 10 & 20 \\
\hline Inferences & 40 & 80 & 10 & 20 \\
\hline Explanation & 40 & 80 & 9 & 20 \\
\hline
\end{tabular}

\subsection{Correlation between Critical Thinking Dispositions and Critical thinking skills}

Critical thinking skills are manifested in actions or behavior. Skilled individuals will be better at doing tasks with fewer mistakes when compared to less skilled individuals when given the same task [9][10][11]. The disposition of critical thinking is attitude/character and can be developed [11]. Critical thinking disposition and critical thinking skills are essential parts of critical thinking that are mutually reinforcing. They are related and interrelated. A person needs a critical thinking disposition to use critical thinking skills.

Researchers have investigated the relationship between critical thinking disposition and critical thinking skills of pre-service science teachers. A simple correlation test is used to explain the relationship between critical thinking dispositions and the critical thinking skills of pre-service science teachers. The data that has been collected using statistical tests (Spearman correlation test) are presented in Table 7 .
Table 7. Correlation between CTDI and CTST

\begin{tabular}{|c|c|c|c|}
\hline & orrelations & CTDI & CTST \\
\hline Spearman's & CTDI Correlation & 1.000 & $0.735^{\star \star}$ \\
\hline & Coefficient & & \\
\hline & Sig. (2 tailed) & & 0.000 \\
\hline & $\frac{\mathrm{N}}{\text { CTCT }}$ & $\frac{50}{735 * *}$ & \\
\hline & $\begin{array}{l}\text { Coefficient } \\
\text { Correlation }\end{array}$ & $0.735^{\star \star}$ & 1.000 \\
\hline & Sig. (2 tailed) & 0.000 & 50 \\
\hline & & & \\
\hline
\end{tabular}

The coefficient of correlation between critical thinking disposition and critical thinking skills of preservice science teachers is 0.735 . It means that the relationship between critical thinking disposition and critical thinking skills of pre-service science teachers is high. The p-value for both sides are 0,000 which is smaller than the value of significance level $\alpha=0.05$ $(0,000<0.05)$. Therefore, Ho is accepted; it means that there is a correlation between critical thinking dispositions and critical thinking skills of pre-service science teachers. The researcher concludes that there is a significant correlation between critical thinking dispositions and the critical thinking skills of preservice science teachers. 


\subsection{Pre-service science teachers' Critical Thinking Dispositions and Critical thinking skills}

This study's pre-service science teachers' critical thinking dispositions and critical thinking skills are still low and underdeveloped. 62\% of pre-service science teachers' critical thinking disposition is at a low level. This response is shown based on the low level of pre-service science teachers' critical thinking dispositions in confidence in reasoning, truthseeking, and analyticity. This result indicates that the pre-service science teachers still cannot find and prove the information/knowledge bravely. The preservice science teachers also still cannot judge and give the right reason. They are still not confident in the power of their thinking.

In critical thinking skills, $82 \%$ of pre-service science teachers have critical thinking skills score at range 1-2 or at not yet visible or still underdeveloped level. The critical thinking skills of pre-service science teachers are still low at evaluation, inference, and explanation on the phenomena and data provided in the instruments. This finding implies that preservice science teachers' critical thinking dispositions and critical thinking skills are still low.

The previous studies show that the critical thinking dispositions of pre-service science teachers are still low and still need to be improved [16]. Disposition holds an essential role in an individual because to become a successful critical thinker. A person needs critical thinking skills that are part of cognitive skills and needs to develop critical thinking dispositions. Critical thinking disposition and critical thinking skills are two mutually reinforcing components and become a characteristic that a person thinks critically or not.

There is a positive and significant correlation between pre-service science teachers' critical thinking dispositions and critical thinking skills as presented in Table 7. Pre-service science teachers' dispositions or critical thinking skills still need to be taught and developed. Critical thinking not only needs skills to judge a reason correctly but also willingness and disposition as a basis of action and belief in a reason [8]. Critical thinking disposition is strongly affected by both attitude and critical thinking in an individual.

The results of this research that have been obtained support the previous studies that showed a positive and significant correlation between critical thinking dispositions and critical thinking skills [12][13]. Critical thinking disposition and critical thinking skills are two different things in an individual. However, critical thinking disposition and critical thinking skills will strengthen each other. Both critical thinking dispositions and critical thinking skills can be taught together in the learning process [9][11][18]. The development of critical thinking needs good planning through a learning process that implements various kinds of learning models which are suitable with the condition of the students and suitable with the learning material [19][20][21].

\section{CONCLUSION}

Pre-service science teachers' critical thinking dispositions and critical thinking skills are at a low level and underdeveloped. Pre-service science teachers' critical thinking dispositions and critical thinking skills still need to be taught and developed. The results of this research also showed a significant relationship between critical thinking disposition and critical thinking skills of pre-service science teachers (correlational coefficient is 0.735). Therefore, both disposition and critical thinking skills must be trained and developed simultaneously in the learning process. Teachers can plan a good learning process by applying various appropriate learning models to develop pre-service science teachers' disposition and critical thinking skills.

\section{AUTHORS' CONTRIBUTIONS}

All authors conceived and designed this study. All authors contributed to the process of revising the manuscript, and in the end, all authors have approved the final version of this manuscript.

\section{REFERENCES}

[1] R. Rafzan, D. Budimansyah, Rahmat, S. Fitriasari, Development of critical thinking skills through the citizenship education course in the era of industrial revolution 4.0, Proceedings of the Second Annual Civic Education Conference (ACEC 2019), Advances in Social Science, Education and Humanities Research, vol. 418, 2020, pp. 256-261. DOI: https://doi.org/10.2991/assehr.k.200320.050

[2] W. Tangahu, A. Rahmat, R. Husain, Modern Education In Revolution 4.0, International Journal Of Innovations In Engineering Research And Technology (IJIERT) 8(1), (2021) 1-5.

[3] K. Ulger, The Effect of Problem-Based Learning on the Creative Thinking and Critical Thinking Disposition of Students in Visual Arts Education, Interdisciplinary Journal of Problem-Based 
Learning 12(1), (2018). 1-18. DOI: https://doi.org/10.7771/1541-5015.1649

[4] S. Ridho, S. Wardani, S. Saptono, Development of Local Wisdom Digital Books to Improve Critical Thinking Skills through Problem Based Learning, Journal of Innovative Science Education, 10(1), (2021). 1-7. DOI: https://doi.org/10.15294/jise.v9i1.37041

[5] R.H. Ennis, The Nature of Critical Thinking: An Outline of Critical Thinking Dispositions and Abilities. University of Illinois, 2011.

[6] G. Bassham, G., Irwin, W., Nardone, H., J.M. Wallace, Critical thinking: A student's introduction (4th ed.). New York: McGraw Hill, 2011.

[7] M. Lyod, N. Bhar, Thinking Critically about Critical Thinking in Higher Education, International Journal for the Scholarship of Teaching and Learning 4 (2), (2010). 1-16. DOI:

https://doi.org/10.20429/ijsotl.2010.040209

[8] F. Kanik, An Assessment Of Teachers' Conceptions of Critical Thinking and Practices for Critical Thinking Development at Seventh Grade Level. The Department Of Educational Sciences, 2010.

[9] R. H. Ennis, Goals for a critical thinking curriculum and its assessment. In Arthur L. Costa (Ed.), Developing minds (3rd Edition). Alexandria, VA: ASCD. Pp. 44-46, 2002.

[10]P.M. King,K.S. Kitchener, Developing Reflective Judgment: Understanding and Promoting Intellectual Growth and Critical Thinking in Adolescents and Adults. San Francisco: Jossey-Bass, 1994.

[11]P.A. Facione, Critical thinking: What it is and why it counts. Millbrae. California: California Academic Press, 2015.

[12] G. Ali, and R.N. Awan, Thinking based instructional practices and academic achievement of undergraduate science students: Exploring the role of critical thinking skills and dispositions, Journal of Innovative Sciences, 7(1) (2021) 56-70. DOI: http://dx.doi.org/10.17582/journal.jis/2021/7.1.5 $\underline{6.70}$

[13]R. Bell., M. Loon, The Impact of Critical Thinking Disposition on Learning using Business Simulations. International Journal of Management Education 13(2), (2015) 119-127. DOI: https://doi.org/10.1016/j.ijme.2015.01.002

[14] F.S. Kirmizia, C. Saygib, and I.H. Yurdaka, I.H., "Determine The Relationship Between The Disposition of Critical Thinking and The Perception About Problem Solving Skills,"
Procedia - Social and Behavioral Sciences 191. $\begin{array}{llll}\text { (2015) } & 657 & - & 661 .\end{array}$ https://doi.org/10.1016/j.sbspro.2015.04.719

[15] S. Sendag, O. Erol, S. Sezgin, N. Dulkadir, Preservice Teachers' Critical Thinking Dispositions and Web 2.0 Competencies. Contemporary Educational Technology 6(3) (2015), 172-187. DOI: https://doi.org/10.30935/cedtech/6148

[16] Fitriani, H., Asy'arI, M., Zubaidah, S. \& Mahanal, S. Critical Thinking Disposition of Prospective Science Teachers at IKIP Mataram, Indonesia. Journal of Physics: Conf. Series. 1108.(2018) 1-6. DOI: https://doi.org/10.1088/17426596/1108/1/012091

[17] J.R. Fraenkel, N.E. Wallen, H.H. Hyun, How to Design and Evaluate Research in Education (8th ed.). New York: McGraw-Hill, 2012.

[18] N.C. Facione, P.A. Facione, Sánchez, C.A. Giancarlo, Critical thinking Disposition as a Measure of Competent Clinical Judgment: The development of the California Critical thinking Disposition Inventory, Journal of Nursing Education, 33(8). (1994) 345-350. DOI: https://doi.org/10.3928/0148-4834-19941001-05

[19] Yusnaeni, A.D. Corebima, H. Susilo, S. Zubaidah, Creative thinking of low academic student undergoing search solve create and share learning integrated with metacognitive strategy, International Journal of Instruction 10(2) (2017) 245-262.

DOI: https://doi.org/10.12973/iji.2017.10216a

[20] S. Mahanal, S. Zubaidah, A. Bahri, S. Dinnurriyah, Improving students' critical thinking skills through Remap NHT in Biology classroom, in Asia-pasific forum on science learning and teaching 17(2), 2017.

[21] Pu, D., Ni, J., Song, D., Zhang, W., Wang, Y., Wu, L., \& Wang, Y. Influence of critical thinking disposition on the learning efficiency of problem-based learning in undergraduate medical students. BMC medical education, 19(1), (2019)

$1-8$. https://doi.org/10.1186/s12909-018-1418-5 